\title{
Bermain Peran: Sebuah Metode untuk Meningkatkan Kemampuan Bahasa Ekspresif Anak
}

\author{
Sri Yuniati ${ }^{1}$, Prima Suci Rohmadheny $\varpi_{2}$ \\ Pendidikan Guru Pendidikan Anak Usia Dini, Universitas Ahmad Dahlan \\ DOI: $10.31004 /$ obsesi.v5i1.509
}

\begin{abstract}
Abstrak
Menggambarkan pelaksanaan pembelajaran dengan metode bermain peran dan mendeskripsikan peningkakan kemampuan bahasa ekspresif anak usia 4-5 tahun di TK ABA Tegalsari Banguntapan Bantul adalah tujuan penelitian ini. Penelitian Tindakan Kelas ini menggunakan Model Kemmis dan Mc Taggart dalam 2 siklus. Sebanyak 20 anak menjadi subyek. Data dikumpulkan menggunakan observasi dan dokumentasi. Data kualitatif dianalisis menggunakan model Miles\&Huberman dan data kuantitatif menggunakan analisis deskriptif. Kriteria keberhasilan tindakan sebesar 70\%. Perbaikan pembelajaran ditunjukkan sebagai berikut: (1) kegiatan transisi sebelum main berjalan baik; (2) diskusi pemeranan dan alur cerita lebih detil; (3) media semakin menarik; (4) kegiatan recalling semakin interaktif; (5) penguatan bahasa anak semakin baik; (6) interaksi dan komunikasi anak semakin baik. Hasil pratindakan menunjukkan $15 \%$ anak mencapai kriteria berkembang sesuai harapan (BSH). Setelah siklus I, prosentase tersebut menjadi 50\% dan akhir siklus II menjadi 80\%. Dengan demikian, pembelajaran metode bermain peran yang dilaksanakan dengan benar telah meningkatkan kemampuan bahasa ekspresif anak.
\end{abstract}

Kata Kunci: anak usia dini; bahasa ekspresif; metode bermain peran

\begin{abstract}
Describing the implementation of learning using the role playing method and specifying the improvement of expressive language skills of children aged 4-5 years at TK ABA Tegalsari Banguntapan Bantul is the purpose of this study. This Classroom Action Research uses Kemmis and Mc Taggart's Models in 2 cycles. As many as 20 children were the subjects. Data collected using observation and documentation. Qualitative data were analyzed using the Miles \& Huberman model and quantitative data using descriptive analysis. Success criteria for action by $70 \%$. Improved learning is shown as follows: (1) transition activities before play goes well; (2) a more detailed discussion of the role and storyline; (3) the media is getting more attractive; (4) increasingly interactive recalling activities; (5) the strengthening of children's language is getting better; (6) children's interaction and communication are getting better. Preaction results show $15 \%$ of children reach the criteria of developing as expected (BSH). After the first cycle, the percentage becomes $50 \%$, and the end of the second cycle becomes $80 \%$. Thus, learning the role playing method that is implemented correctly has increased the expressive language skills of children.
\end{abstract}

Keywords: early childhood education; roleplaying; expressive language skill.

Copyright (c) 2019 Sri Yuniati, Prima Suci Rohmadheny

$\triangle$ Corresponding author:

Email Address : prima.rohmadheny@pgpaud.uad.ac.id (Jl. Ki Ageng Pemanahan No.19, Surosutan,

Yogyakarta, Indonesia)

Received 31 March 2020, Accepted 29 April 2020, Published 30 April 2020 


\section{PENDAHULUAN}

Anak usia dini adalah individu yang berusia 0-8 tahun, yang sedang mengalami proses pertumbuhan dan perkembangan secara pesat. Rentang usia tersebut sering disebut sebagai masa golden age. Pada usia tersebut, anak usia dini memiliki kehidupan dengan karakteristik yang unik dan khas dari segi fisik, psikis, sosial, dan moral. Pendidikan pada anak usia dini lebih difokuskan pada seluruh aspek pengembangan, kepribadian dan potensi anak secara maksimal. Aspek yang dikembangkan diantaranya yaitu aspek bahasa, sosial emosional, seni, nilai agama dan moral, kognitif dan fisik (Indonesia, 2014a). Salah satu aspek penting dari keenam aspek tersebut yaitu aspek bahasa.

Bahasa merupakan alat komunikasi baik secara lisan, tulisan atau menggunakan lambang serta simbol (Santrock, 2007). Kemampuan berbahasa anak prasekolah akan tumbuh dan berkembang dengan pesat secara beragam dan komprehensif (Morrison, 2012), sehingga pemberian stimulasi bahasa untuk anak usia dini perlu dikembangkan secara maksimal agar dapat menjadi bekal di masa depan nanti. Ketika berada di sekolah, guru memiliki tugas untuk menstimulasi perkembangan anak. Kemampuan berkomunikasi anak dibagi menjadi 2, yaitu bahasa reseptif dan bahasa ekspresif (Otto, 2015). Bahasa reseptif mengacu ada pemahaman kata atau simbol dan bahasa eskpresif lebih pada pengolahan bunyi-bunyi ujaran (Otto, 2015).

Menurut Clara dan Stern, tahap perkembangan bahasa dibagi menjadi 4 tahapan antara lain: (a) kalimat satu kata pada usia satu tahun sampai dengan satu tahun enam bulan; (b) Masa memberi nama pada satu setengah sampai dengan 2 tahun; (c) Masa kalimat tunggal pada dua tahun sampai dengan dua setengah tahun; (d) Masa kalimat majemuk pada dua tahun enam bulan dan seterusnya (Zulkifli, 2012). Empat tahapan tersebut akan dilalui setiap anak sesuai dengan tahap dan umur. Sehingga setiap anak akan mampu berbahasa dengan baik.

Berikutnya, Kementerian Pendidikan dan Kebudayaan Nasional menetapkan Standar Pencapaian Perkembangan Anak (STTPA) yang lebih aplikatif digunakan sebagai acuan di Lembaga PAUD melalui peraturan Kementerian Pendidikan dan Kebudayaan Nasional. Berdasarkan peraturan tersebut, capaian perkembangan anak usia 4-5 tahun pada dimensi mengungkapkan bahasa ekspresif terdiri dari: (a) kemampuan dalam mengulang kalimat sederhana; (b) kemampuan bertanya menggunakan kalimat yang benar; (c) kemampuan menjawab pertanyaan dengan tepat sesuai dengan pertanyaan yang disampaikan; (d) kemampuan dalam mengungkapkan perasaan yang menggunakan kata sifat (misalnya: nakal, baik, senang, pelit, berani, baik hati, jelek dsb); (e) kemampuan menyebutkan kosa kata yang telah dikenal; (f) kemampuan mengemukakan pendapatnya kepada orang lain; (g) kemampuan menyatakan alasan terhadap sesuatu hal yang diinginkan atau yang tidak diinginkan; (h) kemampuan menceritakan kembali cerita atau dongeng yang pernah didengar; (i) kemampuan dalam memperkaya perbendaharaan kata; (j) kemampuan berpartisipasi dalam suatu percakapan (Indonesia, 2014a).

Kemudian, capaian perkembangan anak tersebut dalam proses pembelajaran diturunkan ke dalam kompetensi dasar. Berdasarkan kurikulum 2013 PAUD, standar capaian perkembangan bahasa anak usia 4-5 tahun, khususnya pada kemampuan bahasa ekspresif ditunjukkan dengan pencapaian KD 3.11 yang terdiri dari pemahaman atas bahasa ekspresif atau pengungkapan bahasa secara verbal maupun non verbal dan KD 4.11 menunjukkan pada kemampuan berbahasa ekspresif atau pengungkapan bahasa secara verbal dan non verbal dengan beberapa indikator. Beberapa indikator tersebut: (a) mengungkapkan keinginan, perasaan, dan pendapat dengan kalimat sederhana dalam berkomunikasi dengan anak atau orang dewasa; (b) menunjukkan perilaku senang membaca buku terhadap buku-buku yang dikenali; (d) mengungkapkan perasaan, ide dengan pilihan kata yang sesuai ketika berkomunikasi; (e) menceritakan kembali isi cerita secara sederhana (Indonesia, 2014b). Pada kurikulum 2013 PAUD yang diterapkan di lingkungan Lembaga di abwah naungan 'asyiyah provinsi Yogyakarta, indikator untuk kompetensi dasar 3.11 dan 
4.11 di atas, meliputi: (a) mengulang 5-6 kata untuk komunikasi; (b) mempunyai kemampuan merespon dengan tepat saat diajak komunikasi; (c) mampu menjawab dengan tepat ketika ditanya; (d) senang melihat buku cerita; (e) mampu mengemukakan keinginan; (f) mengenal macam-macam bunyi Bahasa (ritme, volume, nada, dan kata); dan (g) mampu berbicara dengan jelas dan lengkap (Tim, 2019).

Salah satu lembaga yang menerapkan kurikulum 2013 PAUD dengan indikator yang dikembangkan oleh tim kurikulum di lingkungan 'Aiyiyah adalah TK ABA Tegalsari, Bantul, Daerah Istimewa Yogyakarta. Berdasarkan data hasil asesmen awal guru pada bulan Juli sampai bulan September 2019 di kelompok A3 usia 4-5 tahun di TK ABA Tegalsari kemampuan bahasa ekspresif anak dalam hal mengungkapkan pendapat belum berkembang sesuai harapan. Hal tersebut ditunjukkan masih rendahnya kemampuan anak dalam mengungkapkan pendapat ketika kegiatan apersepsi, menjawab pertanyaan sesuai pertanyaan dan mengulang kalimat sederhana. Ditemukan sebanyak 17 dari 20 anak atau 85\% anak dikelompok A3 kemampuan bahasa ekspresif belum berkembang. Kemudian, pada bulan November 2019 guru dan peneliti melakukan evaluasi reflektif pembelajaran dengan hasil sebagai berikut: pembelajaran yang menstimulasi kemampuan bahasa anak cenderung monoton, kurang variatif sehingga membuat anak kurang tertarik. Pemberian pijakan sebelum main kurang berjalan dengan baik dan cenderung terburu-buru, sehingga jelas dan kurang detil. Guru telah melakukan metode bermain peran akan tetapi dalam pemberian pijakan sebelum main belum berjalan dengan baik sehingga anak kurang memahami aktifitas peran yang harus dilakukan. Selain itu, guru juga masih kurang memberikan inspirasi atau gagasan main yang dapat memotivasi anak melakukan aktifitas yang menunjukkan bahasa ekspresif.

Ada berbagai metode dalam mengembangkan bahasa ekspresif diantaraya metode bercerita dan bermain peran. Metode bercerita menggunakan media boneka tangan Mucca mampu meningkatkan kemampuan bahasa ekspresif anak (Anggalia \& Karmila, 2014). Selain itu media gambar seri juga dapat meningkatkan kemampuan berbicara pada anak usia dini (Aprinawati, 2017). Menceritakan kembali cerita juga dapat mengembangkan kemampuan bahasa anak (Fauziddin, 2017). Menurut penelitian metode bermain peran dapat meningkatkan kemampuan bahasa ekspresif anak (Amri, 2017; Musi \& Winata, 2017; Putri, 2018; Widiyati \& Saputri, 2016; Yurike \& Sofia, 2018). Bermain peran yaitu suatu kegiatan yang diperankan seseorang sehingga memiliki pemahaman dan pandangan yang benar tentang suatu peristiwa yang akan membawa manfaat bagi anak kedalam kehidupannya (Siregar, 2018). Bermain peran merupakan salah satu metode yang telah diterapkan di TK ABA Tegalsari namun menurut hasil reflesi guru dan peneliti, metode tersebut belum dilakukan secara optimal sesuai dengan tahapan yang semestinya. Menurut Shaftel dan shaftel ada 8 tahapan dalam pembelajaran bermain peran yaitu: (a) memberi penjelasan aturan main; (b) menciptakan suasana agar anak termotivasi bermain peran; (c) memilih peran; (d) menyusun tahapan bermain peran; (e) mempersiapkan pengamat; (f) pemeranan; (g) berdiskusi; (h) kesimpulan (Haenilah, 2015). Oleh sebab itu, penelitian ini dilakukan untuk mendeskripsikan pelaksanaan tindakan metode bermain peran dalam meningkatkan bahasa ekspresif dan menggambarkan adanya peningkatan kemampuan bahasa ekspresif anak usia 4-5 tahun di TK ABA Tegalsari.

\section{METODOLOGI}

Penelitian yang digunakan adalah Penelitian Tindakan Kelas (PTK) dengan model Kemmis dan Taggart dan dilakukan dalam 2 siklus. Masing-masing siklus telah dilaksanakan dalam 4 kali pertemuan, sehingga total ada 8 kali pertemuan. Penelitian tindakan kelas merupakan suatu pengamatan yang dilakukan guru dalam kegiatan belajar yang berupa tindakan yang secara sengaja dimunculkan dan terjadi dalam kelas (Arikunto et al., 2014). Berikut ini desain pelaksanaan tindakan pada setiap siklus. 
Tabel 1. Desain Pelaksanaan Tindakan

\begin{tabular}{|c|c|c|c|c|}
\hline $\begin{array}{l}\text { Siklus } \\
\text { Ke- }\end{array}$ & $\begin{array}{l}\text { Pertemuan } \\
\text { Ke- }\end{array}$ & Tindakan & Tema/Subtema & Media \& Sumber Belajar \\
\hline \multirow[t]{4}{*}{ I } & 1 & $\begin{array}{l}\text { Bermain } \\
\text { peran makro }\end{array}$ & Binatang/ayam & $\begin{array}{l}\text { Ayam mainan, kandang ayam, meja, } \\
\text { kursi, gelas, sendok, kompor, uang } \\
\text { mainan, mobil-mobilan, timbangan, } \\
\text { telepon }\end{array}$ \\
\hline & 2 & $\begin{array}{l}\text { Bermain } \\
\text { peran mikro }\end{array}$ & Binatang/sapi & $\begin{array}{l}\text { Sapi mainan, rumput sintesis, miniatur } \\
\text { rumah, mobil-mobilan, lego, orang- } \\
\text { orangan }\end{array}$ \\
\hline & 3 & $\begin{array}{l}\text { Bermain } \\
\text { peran mikro }\end{array}$ & Binatang/bebek & $\begin{array}{l}\text { Lego, bebek mainan, mobil-mobilan, } \\
\text { orang-orangan, meja, kursi }\end{array}$ \\
\hline & 4 & $\begin{array}{l}\text { Bermain } \\
\text { peran makro }\end{array}$ & Binatang/kucing & $\begin{array}{l}\text { Kucing asli, kucing maianan, tempat } \\
\text { tidur, perlengkapan makan, } \\
\text { perlengkapan medis, sayuran mainan, } \\
\text { meja, kursi, nampan, baju dokter }\end{array}$ \\
\hline \multirow[t]{4}{*}{ II } & 1 & $\begin{array}{l}\text { Bermain } \\
\text { peran makro }\end{array}$ & Binatang/ikan & $\begin{array}{l}\text { Ikan tetra, ikan balon, ikan mas, ikan } \\
\text { koi, aquarium, jaring, pancing, } \\
\text { panggangan, nampan, piring, gelas, } \\
\text { uang mainan }\end{array}$ \\
\hline & 2 & $\begin{array}{l}\text { Bermain } \\
\text { peran mikro }\end{array}$ & $\begin{array}{l}\text { Binatang/kura- } \\
\text { kura }\end{array}$ & $\begin{array}{l}\text { Kura-kura, balok-balok, orang-orangan, } \\
\text { mobil-mobilan, gambar pantai }\end{array}$ \\
\hline & 3 & $\begin{array}{l}\text { Bermain } \\
\text { peran makro }\end{array}$ & Binatang/lele & $\begin{array}{l}\text { Meja, kursi, lele asli, lele dari flanel, } \\
\text { uang mainan, aneka sayuran dan buah- } \\
\text { buahan dari plastik }\end{array}$ \\
\hline & 4 & $\begin{array}{l}\text { Bermain } \\
\text { peran mikro }\end{array}$ & Binatang/burung & $\begin{array}{l}\text { Burung, sangkar, meja, kursi, bunga, } \\
\text { pot, bantal, selimut, pakaian parkir, } \\
\text { peluit }\end{array}$ \\
\hline
\end{tabular}

Berdasarkan desain di atas, maka dapat dilihat bahwa tindakan dilaksanakan dengan variasi metode bermain peran makro dan mikro serta variasi bantuan media dan sumber belajar yang digunakan sebagai properti selama bermain peran. Penelitian tindakan ini dilakukan dengan kolaborasi antara guru dengan peneliti. Subyek penelitian ini adalah anak kelompok A3 yang berjumlah 20 orang. Penelitian dilaksanakan pada sebulan di TK ABA Tegalsari Banguntapan Bantul pada tahun ajaran 2019/2020. Data dikumpulkan menggunakan menggunakan Teknik observasi dan dokumentasi. Kemudian, data kualitatif dianalisis menggunakan model Miles\&Hubberman, sedangkan analisis data kuantitatif menggunakan analisis deskriptif (prosentase) dengan kriteria keberhasilan tindakan yang disepakati bersama kolaborator sebesar $70 \%$.

\section{HASIL DAN PEMBAHASAN}

\section{Aktivitas Bahasa Ekspresif}

Pada siklus I belum banyak anak yang aktif menunjukan kemampuan bahasa ekspresifnya, hanya 5 dari 20 anak yang mampu berinteraksi dan berkomunikasi ketika bermain peran ataupun kegiatan recalling. Dalam melakukan kegiatan recalling, interaksi dan komunikasi anak kurang berjalan dengan baik disebabkan oleh guru yang masih belum optimal memberi kesempatan pada anak dan terkesan terburu-buru memberikan bantuan kepada anak dalam menjawab pertanyaan yang diajukan. Perbedaan aktivitas bahasa ekspresif anak sebelum tindakan dan setelah tindakan pada siklus I yaitu sebelum dilakukan tindakan pada saat apersepsi, anak belum mampu menjawab pertanyaan dengan jawaban yang tepat dan belum mampu mengulang kalimat sederhana dengan benar. 
Pada siklus II, interaksi dan komunikasi hampir semua anak berjalan dengan baik selama kegiatan bermain peran. Anak-anak mampu menggunakan alat mainnya untuk bermain peran mikro, bercakap-cakap dengan teman sesuai peran dan alur cerita yang telah diberikan saat pijakan sebelum main. Ekplorasi alat main untuk bermain peran memberi kesempatan anak untuk mengembangkan bahasa lisannya (Riswanti, 2016). Alat main tersebut menjadi properti bagi anak saat bermain peran, hal tersebut mendukung kemampuan anak dalam melakukan main peran dengan baik (Wahyuni \& Priyatni, 2012; Yurike \& Sofia, 2018). Media dapat berupa wayang, mobil-mobilan, boneka tangan, boneka jari. Boneka tangan dapat menjadi alat bantu bercerita yang meningkatkan keterampilan berbicara anak (Suradinata \& Maharani, 2020).

Kegiatan recalling telah dilakukan guru berjalan dengan baik, tampak adanya interaksi dan komunikasi antara anak dengan guru melalui percakapan. Bercakap-cakap yang dilakukan anak dengan temannya atau anak dengan guru merupakan sarana untuk meningkatkan keterampilan berbicara anak (Khoiriyah \& Rachman, 2019). Anak mampu mengulang kalimat sederhana dengan benar, menjawab pertanyaan sesuai dengan pertanyaan yang diserikan dan mampu mengutarakan pendapatnya dengan baik.

\section{Proses Pelaksanaan Pembelajaran dengan Metode Bermain Peran}

Penerapan metode bermain peran sebelum tindakan dan setelah siklus I mulai ada perubahan pada upaya guru dalam menerapkan metode bermain peran. Pada siklus I guru telah melakukan pijakan sebelum main dengan jelas, menjelaskan aturan main selama main peran, memberikan kesempatan anak memilih peran yang disukai. Guru menjelaskan pemeranan dan alur cerita yang akan dimainkan kurang detail dan terburu-buru sehingga anak bingung ketika bermain peran. Media yang digunakan guru kurang menarik dan anak mudah bosan untuk memainkannya. Akan tetapi, pada saat kegiatan recalling guru masih memberikan bantuan kepada anak dalam menjawab pertanyaan yang diajukan guru. Halhal tersebut menjadi poin penting dalam refleksi sebagai bahan perbaikan pada siklus II.

Tindakan yang dilakukan guru pada siklus I khususnya saat kegiatan transisi sebelum main menunjukkan masih adanya kesan terburu-buru selama mendiskusikan pemeranan dan alur cerita belum detil. Media yang digunakan guru juga tampak belum cukup menarik bagi anak, hal tersebut tampak dari respon anak yang cepat bosan. Guru masih memberikan bantuan ke anak dalam recalling, guru dalam pemberian penguatan bahasa masih kurang optimal.

Pada siklus II, selama proses proses pelaksanaan bermain peran menunjukkan bahwa guru telah melakukan upaya perbaikan dalam melaksanakan 8 tahapan metode bermain peran sehingga berjalan dengan baik dan benar. Tahapan tersebut telah sesuai dengan tahapan bermain peran menurut Shaftel \& Shaftel (Haenilah, 2015). Proses pembelajaran yang pada siklus I masih belum baik, telah diperbaiki oleh guru pada siklus II.

Guru telah menyediakan media pembelajaran yang menarik bagi anak. Media yang digunakan dalam pembelajaran bagi anak usia dini adalah alat bantu untuk mencapai kompetensi yang diharapkan sesuai dengan tema dan sub tema yang telah ditetapkan, dimana media tersebut lebih dapat mengoptimalkan pemberdayaan seluruh indera anak selama bermain peran. Proses pembelajaran yang melibatkan banyak indra akan membuat anak lebih mudah mengerti materi yang disampaikan guru (Saurina, 2016).

Penggunaan media sebagai properti dalam mendukung keterlaksanaan proses pembelajaran menggunakan metode bermain peran dalam penelitian ini menunjukkan bahwa peserta didik lebih tertarik untuk terlibat aktif dan properti tersebut membangkitkan daya imajinasi mereka. Keterlibatan aktif tersebut menjadi peluang bagi anak-anak untuk mengeskpresikan imajinasinya menjadi sebuah cerita dan interaksi anak melalui bahasanya. Sebuah penelitian menyebutkan bahwa anak-anak yang mendapatkan stimulasi menggunakan media akan memiliki perbendaharaan kata lebih banyak serta ada 
peningkatan kemampuan fonasi dan konsep cerita yang lebih baik dibandingkan dengan anak yang tidak mendapat stimulasi media (Rahmawati et al., 2016).

Selain itu, kegiatan transisi juga telah dilakukan guru dengan baik, guru telah melakukan recalling tanpa memberikan bantuan dan anak-anak sudah bisa menceritakan apa yang sudah dimainkan dan mengungkapkan perasaan selama main peran serta guru melakukan penguatan bahasa dengan pengulangan dan mendampingi anak yang kesulitan dalam mengungkapkan perasaan, ide dan gagasan. Aktivitas recalling juga memberi kesempatan bagi anak berinteraksi dengan guru menggunakan bahasa lisan. Kemampuan awal anak-anak dalam mengekspresikan diri mereka secara efektif dalam sebuah interaksi dan komunikasi dengan orang lain dapat membantu mereka alam membangun hubungan sosial yang lebih baik (Girard et al., 2017), serta menjadi bekal kesiapan sekolah anak ke jenjang selanjutnya (Goble \& Pianta, 2017; Hatfield et al., 2016).

\section{Peningkatan Kemampuan Bahasa Ekspresif}

Peningkatan kemampuan bahasa ekspresif anak pada pratindakan ke siklus I mengalami sedikit peningkatan. Pada kriteria berkembang sesuai harapan pratindakan ada 3 anak dan di siklus I ada 10 anak dari 20 anak. Ada peningkatan yang signifikan setelah dilakukan perbaikan pada siklus II. Terdapat 16 anak dari 20 anak pada kriteria berkembang sesuai harapan. Pada kedua siklus yang telah dilaksanakan sudah tidak ditemukan anak yang berada dalam kriteria belum berkembang. Prosentase peningkatan tersebut secara bertahap dapat dicermati sebagai berikut.

Peningkatan kemampuan bahasa ekspresif pada siklus I dapat dibandingkan dengan kemampuan bahasa ekspresif anak ketika pratindakan. Kemampuan bahasa ekspresif sebelum tindakan mencapai $15 \%$ dalam kriteria berkembang sesuai harapan dan $85 \%$ dengan kriteria mulai berkembang dari 20 anak yang diteliti. Adapun perbandingan peningkatan kemampuan bahasa ekspresif anak sebelum tindakan dan siklus I dapat dilihat pada tabel di bawah ini.

Tabel 2. Perbandingan Kemampuan Bahasa Ekspresif Anak Sebelum Tindakan dan Siklus I

\begin{tabular}{ccccc}
\hline Kriteria Capaian & \multicolumn{2}{c}{ Sebelum Tindakan } & \multicolumn{2}{c}{ Siklus I } \\
& frekuensi & Persentase & frekuensi & Persentase \\
\hline BSB & 0 & $0 \%$ & 0 & $0 \%$ \\
BSH & 3 & $15 \%$ & 10 & $50 \%$ \\
MB & 17 & $85 \%$ & 10 & $50 \%$ \\
BB & 0 & $0 \%$ & 0 & $0 \%$ \\
Total & 20 & $100 \%$ & 20 & $100 \%$ \\
\hline
\end{tabular}

Pada tabel di atas tampak adanya peningkatan yang signifikan setelah dilakukan tindakan pada siklus I. Sebelum dilakukan tindakan, belum ada anak yang masuk kategori berkembang sangat baik (BSB), terdapat 3 anak (15\%) yang berada pada kriteria berkembang sesuai harapan (BSH), dan 17 anak (85\%) berada pada kriteria mulai berkembang (MB). Kemudian setelah tindakan siklus I, kemampuan bahasa ekspresif anak meningkat. Sebanyak 10 anak (50\%) yang berada pada kriteria BSH, 10 anak (50\%) pada kriteria MB. Kondisi tersebut menunjukkan bahwa ada penurunan jumlah anak yang berada pada kategori MB dan jumlah anak yang berada pada kategori BSH meningkat. Peningkatan ini sejalan dengan berbagai penelitian sebelumnya di mana penggunaan metode bermain peran dapat membantu meningkatkan kemampuan bahasa ekspresif, seperti keterampilan berbicara atau berkomunikasi secara lisan (Inten, 2017; Putri, 2018; Susanti, 2017). 
Akan tetapi, pada siklus I ini belum ada satupun yang berada pada kriteria BSB. Tidak ada anak satupun anak yang berada dalam kriteria BB, baik sebelum pratindakan maupun setelah tindakan siklus I. Hal tersebut menunjukkan bahwa pada dasarnya anakanak sudah memiliki perkembangan meskipun banyak yang belum sesuai dengan harapan. Hal tersebut diindikasikan karena proses pembelajaran yang dilaksanakan oleh guru dan anak masih mengalami beberapa kekurangan. Kekurangan yang dimaksud seperti yang telah disebutkan dalam refleksi siklus antara lain: pijakan sebelum main yang masih terburuburu sehingga diskusi pemeranan dan alur cerita kurang detil, media yang digunakan guru belum cukup menarik bagi anak, sehingga anak yang cepat bosan. Ketika recalling, guru masih banyak memberi bantuan menjawab sehingga kurang interaktif. Pemberian penguatan bahasa oleh guru kepada anak masih kurang optimal.

Melalui data peningkatkan pada siklus I, dapat dianalisis perbandingannya dengan kriteria keberhasilan tindakan. Melalui hasil perbandingan antara capaian kemampuan Bahasa ekspresif anak pada siklus I yaitu $50 \%$ pada kriteria BSH dengan kriteria keberhasilan tindakan sebesar 70\%, maka dapat disimpulkan bahwa setelah melalui siklus I ini tindakan belum cukup berhasil melampau kriteria keberhasilannya. Oleh sebab itu, peneliti menggunakan hasil refleksi proses pelaksanaan metode bermain peran pada siklus I sebagai dasar dalam memperbaiki rencana tindakan dan tindakan pada siklus II.

Peningkatan kemampuan bahasa ekspresif pada siklus II dapat dibandingkan dengan siklus I. Kemampuan bahasa ekspresif anak setelah dilakukan tindakan pada siklus II mengalami peningkatan. Adapun perbandingan peningkatan kemampuan bahasa ekspresif anak pada siklus I dan siklus II dapat dilihat pada tabel di bawah ini.

Tabel 2. Perbandingan Kemampuan Bahasa Ekspresif Siklus I dan Siklus II

\begin{tabular}{ccccc}
\hline Kriteria Capaian & \multicolumn{2}{c}{ Siklus I } & \multicolumn{2}{c}{ Siklus II } \\
& $\mathrm{f}$ & persentase & $\mathrm{f}$ & persentase \\
\hline BSB & 0 & $0 \%$ & 4 & $20 \%$ \\
BSH & 10 & $50 \%$ & 16 & $80 \%$ \\
MB & 10 & $50 \%$ & 0 & $0 \%$ \\
BB & 0 & $0 \%$ & 0 & $0 \%$ \\
Total & 20 & $100 \%$ & 20 & $100 \%$ \\
\hline
\end{tabular}

Melalui tabel di atas dapat dicermati bahwa kemampuan bahasa ekspresif anak pada siklus I menuju siklus II mengalami peningkatan. Sebagaimana yang telah disajikan sebelumnya bahwa hasil siklus I belum mencapai kriteria keberhasilan tindakan, maka berlanjut pada siklus II dengan memperhatikan hasil refleksi pada siklus I dan dilakukan perbaikan tindakan pada siklus II. Perbaikan proses pembelajaran melalui upaya perbaikan tindakan dari siklus I ke siklus II menunjukkan hasil yang baik pada akhir siklus II.

Pada siklus I belum ada satu pun anak yang mencapai kriteria berkembang sangat baik (BSB), yang artinya kemampuan anak melampaui kemampuan yang diharapkan. Tapi pada siklus II, kondisi tersebut berbeda. Terdapat 4 anak $(20 \%)$ yang awalnya pada kriteria BSH meningkat menjadi BSB. Kemudian pada siklus I masih ada 10 anak (50\%) yang berada pada kriteria MB sudah tidak ada lagi pada akhir siklus II dan ada peningkatan prosesntase capaian anak pada krieria BSH, yaitu sebanyak 16 anak $(80 \%)$.

Berdasarkan temuan hasil di atas, metode bermain peran yang dilaksanakan dengan baik dan benar mampu meningkatkan kemampuan bahasa ekspresif anak. Berikut ini grafik yang menggambarkan peningkatan kemampuan Bahasa ekpresif anak secara keseluruhan dari mulai pratindakan, siklus I, dan siklus II. 


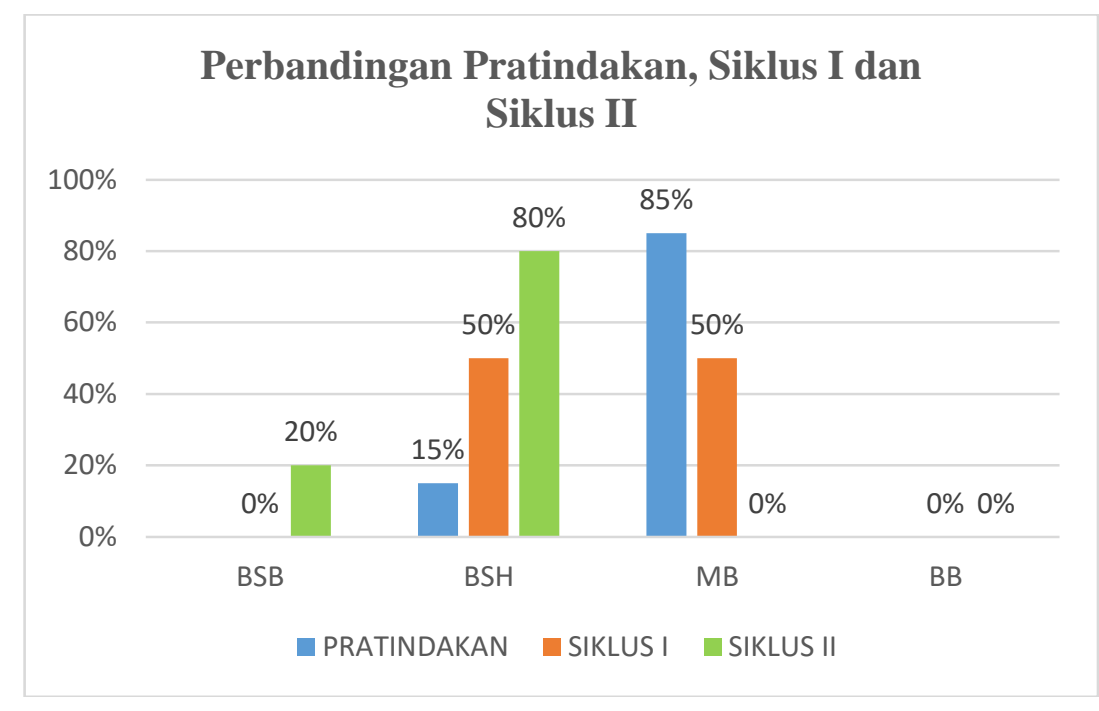

\section{Gambar 1 Diagram Perbandingan Peningkatan Kemampuan Bahasa Ekspresif Anak}

Berdasarkan diagram di atas tampak bahwa terjadi peningkatan kemampuan bahasa ekpresif anak kelas A3 antara pratindakan, siklus I dan siklus II. Pada data pratindakan, hanya $15 \%$ anak masuk kriteria berkembang sesuai harapan. Kemudian, dilakukan tindakan pada siklus I sehingga kemampuan bahasa ekspresif anak meningkat menjadi $50 \%$. Pada siklus I tersebut belum memenuhi ktriteria keberhasilan tindakan sehingga dilakukan perbaikan tindakan pada siklus II. Hasil penilaian kemampuan bahasa ekspesif anak meningkat menjadi $80 \%$. Hasil penelitian tersebut sejalan dengan penelitian yang menyebutkan bahwa metode bermain peran (role playing) efektif terhadap perkembangan bahasa lisan anak (Faizah \& Simatupang, 2016; Sumiati et al., 2018). Karena, bahasa lisan salah satu bentuk bahasa ekpresif. Dengan adanya peningkatan yang telah melalui batas kriteria keberhasilan tindakan, maka siklus II menjadi siklus terakhir dalam penelitian ini.

\section{SIMPULAN}

Peningkatan kemampuan bahasa ekspresif anak seiring dengan peningkatan pelaksanaan proses pembelajaran dengan menggunakan metode bermain peran dengan tahapan yang baik dan benar. Peningkatan yang terlihat pada setiap siklus menunjukkan bahwa metode bermain peran yang digunakan efektif untuk meningkatkan kemampuan bahasa ekspresif anak. Metode bermain peran yang digunakan ada 2 yaitu bermain peran makro yang menggunakan alat permainan yang sesungguhnya dan bermain peran mikro yang menggunakan alat permainan berbentuk kecil. Bermain peran makro ataupun mikro mampu membantu anak dalam kemampuan berbahasa ekspresif anak usia 4-5 tahun.

\section{UCAPAN TERIMAKASIH}

Ucapan terimakasih disampaikan kepada pembimbing dan PG PAUD FKIP Universitas Ahmad Dahlan atas dukungan terhadap penyelesaian penelitian ini.

\section{DAFTAR PUSTAKA}

Amri, N. A. (2017). Pengaruh metode bermain peran terhadap kemampuan komunikasi (bahasa ekspresif) anak Taman Kanak-Kanak Raudhatul Athfal Alauddin Makassar. PEMBELAJAR: Jurnal Ilmu Pendidikan, Keguruan, Dan Pembelajaran, 1(2), 105. https://doi.org/10.26858/pembelajar.v1i2.4864

Anggalia, A., \& Karmila, M. (2014). Upaya meningkatkan kemampuan bahasa ekspresif anak dengan menggunakan media boneka tangan muca (moving mouth puppet) pada 
kelompok A TK Kemala Bhayangkari 01 Semarang. PAUDIA: Jurnal Penelitian Dalam BIdang Pendidikan Anak Usia Dini, 3(2). https:// doi.org/10.33369/jip.2.1.63-70

Aprinawati, I. (2017). Penggunaan media gambar seri untuk meningkatkan kemampuan berbicara anak usia dini. Obsesi, 1(1). https:/ / doi.org/10.31004/obsesi.v1i1.33

Arikunto, Suhardjono, \& Supardi. (2014). Penelitian Tindakan Kelas. PT. Bumi Aksara.

Faizah, U., \& Simatupang, N. D. (2016). Meningkatkan kemampuan berkomunikasi lisan melalui metode bermain peran mikro pada kelompok B. PAUD Teratai, 5(2). https://jurnalmahasiswa.unesa.ac.id/index.php/paud-teratai/article/view/15850

Fauziddin, M. (2017). Upaya peningkatan kemampuan bahasa anak usia 4-5 tahun melalui kegiatan menceritakan kembali isi cerita di kelompok bermain Aisyiyah Gobah kecamatan Tambang. Obsessi, 1(1). https:/ / doi.org/10.31004/obsesi.v1i1.30

Girard, L. C., Pingault, J. B., Doyle, O., Falissard, B., \& Tremblay, R. E. (2017). Expressive language and prosocial behaviour in early childhood: Longitudinal associations in the UK Millennium Cohort Study. European Journal of Developmental Psychology, 14(4), 381-398. https://doi.org/10.1080/17405629.2016.1215300

Goble, P., \& Pianta, R. C. (2017). Teacher-Child Interactions in Free Choice and TeacherDirected Activity Settings: Prediction to School Readiness. Early Education and Development, 28(8), 1035-1051. https://doi.org/10.1080/10409289.2017.1322449

Haenilah, E. (2015). Kurikulum dan Pembelajaran PAUD (pertama). Media Akademi.

Hatfield, B. E., Burchinal, M. R., Pianta, R. C., \& Sideris, J. (2016). Thresholds in the association between quality of teacher-child interactions and preschool children's school readiness skills. Early Childhood Research Quarterly, 36, 561-571. https:/ / doi.org/10.1016/j.ecresq.2015.09.005

Indonesia, R. (2014a). Peraturan Menteri Pendidikan dan Kebudayaan No. 137 tahun 2014 tentang Standar Nasional Pendidikan Anak Usia Dini. Kementerian Pendidikan dan Kebudayaan.

Indonesia, R. (2014b). Peraturan Menteri Pendidikan dan Kebudayaan Republik Indonesia Nomor 146 Tahun 2014 Tentang Kurikulum 2013 Pendidikan Anak Usia Dini. Kementerian Pendidikan dan Kebudayaan.

Inten, D. N. (2017). Pengembangan keterampilan berkomunikasi anak usia dini melalui metode bermain peran. Mediator, 10(1), 109-120. https:// doi.org/10.29313/mediator.v10i1.2712

Khoiriyah, K., \& Rachman, A. U. (2019). Bercakap-cakap sebagai Metode Peningkatan Kemampuan Berbicara Anak. Journal of Early Childhood Care and Education, 2(1), 38. https:// doi.org/10.26555/jecce.v2i1.567

Morrison, G. (2012). Dasar-Dasar Pendidikan Anak Usia Dini (PAUD). Indeks.

Musi, M. A., \& Winata, W. (2017). Efektivitas bermain peran untuk pengembangan bahasa anak. PEMBELAJAR: Jurnal Ilmu Pendidikan, Keguruan, Dan Pembelajaran, 1(2), 93. https:// doi.org/10.26858/pembelajar.v1i2.4418

Otto, B. (2015). Perkembangan Bahasa pada Anak Usia Dini. Prenadamedia Grup.

Putri, M. (2018). Efektivitas Penerapan Metode Bermain Peran Makro Terhadap Perkembangan Bahasa Lisan Anak Di Taman Kanak-Kanak Darul Falah Kota Padang. In Journal of SECE (Vol. 1, Issue 2). https:/ / doi.org/10.31331/sece.v1i2.730

Rahmawati, W., Nugraheni, A., Rahmadi, F. A., Pengajar, S., Ilmu, B., Masyarakat, K., Kedokteran, F., Diponegoro, U., \& Anak, K. (2016). Pengaruh stimulasi media interaktif terhadap perkembangan bahasa anak 2-3 tahun. In Diponegoro Medical Journal (Vol. $\quad 5, \quad$ Issue 4 ). https:/ / ejournal3.undip.ac.id/index.php/medico/article/view/15982

Riswanti, E. P. E. (2016). Eksplorasi Beramin Peran Mikro Anak Usia Dini dalam Meningkatkan Keterampilan Berbicara. In jurnal PAUD. http://jurnal.fkip.unila.ac.id/index.php/PAUD/article/view/11239

Santrock. (2007). Perkembangan Anak (Kesebelas). PT. Erlangga. 
DOI: 10.31004/obsesi.v5i1.509

Saurina, N. (2016). Pengembangan Media Pembelajaran Untuk Anak Usia Dini Menggunakan Augmented Realty. Jurnal IPTEK, 20(1), 95. https:// doi.org/10.31284/j.iptek.2016.v20i1.27

Sumiati, Y., Sobarna, A., \& Inten, D. (2018). Upaya Meningkatkan Kemampuan Berbahasa Ekspresif Pada Anak Usia 5-6 Tahun Melalui Metode Role Playing. http://103.78.195.33/handle/123456789/16458

Suradinata, N. I., \& Maharani, E. A. (2020). Pengaruh bercerita berbantuan media boneka tangan terhadap kemampuan berbicara anak. Journal on Early Childhood Education Research (JOECHER), 1(2), 72-81. https:// doi.org/10.37985/joecher.v1i2.11

Susanti, Y. (2017). Meningkatkan kemampuan berbicara anak melalui bermain peran mikro. Jurnal Ilmiah Potensia, 2(1). https:/ / doi.org/10.33369/jip.2.1.63-70

Tim. (2019). Indikator Kurikulum 2013 PAUD Terintegrasi dengan Al-Islam Kemuhammadiyahan/Ke'aisyiyahan. Pimpinan Pusat 'Aisyiyah Majelis Tabligh.

Wahyuni, E. D., \& Priyatni, E. (2012). Pengaruh penggunaan kostum dan properti terhadap kemampuan bermain peran siswa kelas XI SMA Negeri 2 Malang. In jurnalonline.um.ac.id. http://jurnalonline.um.ac.id/data/artikel/artikel52B6BAA08CD9668994AB33921F9047AF.pdf

Widiyati, S., \& Saputri, M. C. W. (2016). Meningkatkan kemampuan bahasa ekspresif melalui kegiatan bermain peran makro pada kelompok A. Jurnal PAUD Teratai, 05(03), 91-94.

Yurike, I., \& Sofia, A. (2018). Bermain peran dan kemampuan berbahasa anak usia dini. Jurnal Pendidikan Anak, 4(2). http://jurnal.fkip.unila.ac.id/index.php/PAUD/article/view/14589

Zulkifli. (2012). Psikologi Perkembangan (delapan). Remaja Rosdakarya. 